\title{
РОЗГЛЯД ТА ВИРІШЕННЯ ПРОЩЕСУАЛЬНИХ СИТУАЦІЙ, ЯКІ ВИНИКАЮТЬ У КРИМІНАЛЬНИХ ПРОВАДЖЕННЯХ ПРИ ПРИЗНАЧЕННІ ЕКСПЕРТИЗИ В СУДІ
}

\begin{abstract}
ОСМОЛЯН Віталій Анатолійович - кандидат юридичних наук, старший викладач кафедри права, Хмельницький кооперативний торговельно-економічний інститут, місто Хмельницький
\end{abstract}

УДК 343.112

\footnotetext{
В статье автором излагаются правовъге основъ и перспективъ развития судебной экспертизъ и уголовного процессуального права в свете правовой ребормвг в Украине. Рассматриваются процессуальнье ситуаизи, которвие возникают в суде при судебном разбирательстве уголовных дел, исследуются и анализируются вопросы о возможности назначения и проведения экспертизв в уголовном производстве в суде, а также обосновъгвается необходимость эбббективного сотрудничества работников суда и экспертов (специалистов) для качественного и оббективного въгполнения задач уголовного судопроизводства, соблюдения общих принципов уголовного производства и улучшения инновационной политики Украинъ в изелом. Сбормированъ и приведень предложения по улучшению методики назначения экспертизы при рассмотрении уголовных дел судом. Автором предоставлень собственнъие (авторские) предложения по решению возможных процессуальнъхх трудностей при назначении экспертизы в суде. Раскрывается значение и место этих новелл в системе права, судебной экспертизъ и уголовного процесса в иелом. Сделанъ въгводъ и данъ рекомендации по согласованному применению норм действующего законодательства в практической деятельности эксперта и судьи. Привлечено внимание на необходимость дальнейшего научного сотрудничества ученъхх, специалистов в области материального и процессуального права.
}

Ключевъе слова: исследование, экспертиза, суд, судъя, сторонъи, спещиалист, уголовнвий процесс, уголовное производство.

Постановка проблеми

У відповідності до пункту 14 статті 92 Конституції України [1] судоустрій, судочинство та засади судової експертизи визначаються тільки законами України.

Це покладає особливу відповідальність на експертів та суддів (суди) щодо забезпечення швидкого, повного та неупередженого розслідування і судового розгляду 3 тим, щоб кожний, хто вчинив кримінальне правопорушення, був притягнутий до відповідальності в міру своєї вини, жоден невинуватий не був обвинувачений або засуджений, жодна особа не була піддана необгрунтованому процесуальному примусу і щоб до кожного учасника кримінального провадження була застосована належна правова процедура. Зазначене не уявляється можливим без суворого дотримання норм Конституції України та процедури законності. У цьому і полягає актуальність проблеми.

Аналіз останніх досліджень та публікацій

Проведений аналіз [1-8] показав, що вчені та практики неодноразово досліджували діяльність правоохоронних органів та суду по основних питаннях призначення 


\section{Кримінальне право, кримінальний процес та криміналістика}

експертного дослідження в цілому та його окремі аспекти зокрема. Проте розгляд та вирішення процесуальних ситуацій, які виникають у кримінальних провадженнях при призначенні експертизи в суді, вимагає свого детального дослідження та аналізу.

Мета статті - на підставі проведеного теоретичного аналізу та власного практичного досвіду розглянути процесуальних ситуацій, які виникають у кримінальних провадженнях при призначенні експертизи в суді, а також обгрунтувати необхідність ефективної співпраці суддів (суду) та експертів (спеціалістів) для якісного та об'єктивного виконання завдань кримінального провадження, а також покращення інноваційної політики України взагалі.

\section{Виклад основного матеріалу}

Проведення експертизи, участь експерта та спеціаліста у процесуальній дії у кримінальному судочинстві регулюється відповідно Кримінальним процесуальним кодексом України (далі КПК України) [2], Законом України «Про судову експертизу» від 25 лютого 1994 року [3], Законом України «Про психіатричну допомогу» від 22 лютого 2000 року [4], а також відомчими Правилами та інструкціями Міністерства юстиції України та Міністерства охорони здоров’я України з питань проведення експертиз.

Так, у відповідності до Закону України «Про судову експертизу», судова експертиза - це дослідження на основі спеціальних знань у галузі науки, техніки, мистецтва, ремесла тощо об'єктів, явищ і процесів 3 метою надання висновку з питань, що $є$ або будуть предметом судового розгляду [3].

Норми КПК України вказують, що експертом у кримінальному провадженні 6 особа, яка володіє науковими, технічними або іншими спеціальними знаннями, має право відповідно до Закону України «Про судову експертизу» на проведення експертизи і якій доручено провести дослідження об'єктів, явищ і процесів, що містять відомості про обставини вчинення кримінального правопорушення, та дати висновок 3 питань, які виникають під час кримінального провадження і стосуються сфери їі знань (стаття 69 КПК України).

Окрім того, законодавець України вказує на кримінальну відповідальність експерта (спеціаліста) у випадку складання останнім завідомо неправдивого висновку, який складений для надання або наданий органу, що здійснює досудове розслідування, виконавче провадження, суду, а також при відмові експерта без поважних причин від виконання покладених на нього обов'язків (статті 384 та 385 Кримінального кодексу України [5].

Порядок призначення та проведення експертизи в суді у кримінальних справах (провадженнях) регламентується статями: 242, 243, 244, 245, 332, 356, 360, 486, 509 та 518 КПК України [2]. Окрім того, призначаючи та проводячи експертизу, суд керується і вказівками закону, які викладені у першому розділі КПК України «Загальні положення» та також стосуються експертизи (зокрема статті: 23, 69, 70, 71, 72, 79, $80,83,101,102,122)$. Необхідно акцентувати увагу, що якщо приймається рішення про проведення експертизи в судово-експертній установі, суд повинен керуватися також і відомчими нормативними актами, які регулюють питання іiі призначення та проведення у цій установі.

Під час здійснення провадження у справі в суді виникають різні процесуальні ситуації, за яких має бути вирішено питання про необхідність призначення експертизи.

Розглянемо ці ситуації більш детально.

Ситуація перша.

Статті 23 та 370 КПК України встановлюють, що вирок може грунтуватися лише на тих доказах, які були розглянуті та досліджені у судовому засіданні. 3 цієї норми слідує, що висновок експерта, який складено на стадії досудового розслідування, якщо ним встановлено фактичні обставини, що мають значення для вирішення справи, повинен бути перевірений у судовому засіданні.

Виникає логічне запитання: чи обов'язковий у цих випадках виклик у судове засідання експерта? У літературі з цього 
приводу висловлені різні думки. Так, одні автори вважають виклик експерта в судове засідання обов'язковою процесуальною нормою [6]. Інші дослідники висловлюють думку про те, що його участь у судовому засіданні має забезпечуватися лише у необхідних процесуальних випадках [7]. Остання точка зору відображає позиції Пленуму Верховного Суду України, який у постанові від 30 травня 1997 року № 8 зазначив, що у справах, де експертиза проводилася у стадії досудового розслідування, суд повинен забезпечити участь експерта в судовому засіданні у необхідних випадках [8].

На нашу точку зору, виклик експерта в судове засідання є виправданим та доцільним у наступних випадках:

1) коли в судовому засіданні виникає необхідність у проведенні додаткової експертизи;

2) висновок експерта необгрунтований, суперечить іншим матеріалам справи (провадження), має інші недоліки, які викликають сумнів у його правильності;

3) у висновку експерта встановлюється суттєвий для справи факт;

4) при розслідуванні провадження (справи) для встановлення одного й того ж факту проведені дві експертизи та експерти дали суперечливі висновки;

5) при проведенні комісійної експертизи експерти не прийшли до єдиної думки та кожен 3 них склав свій висновок (або виклав окрему думку);

6) зацікавлені учасники процесу заявляють клопотання про необхідність виклику експерта у судове засідання;

7) висновок експерта грунтується лише на взятих із показань підозрюваного, потерпілого, свідка вихідних даних, а тому є підстави вважати, що вони будуть змінені у судовому засіданні;

8) у висновку експерта встановлюються обставини, які сприяли вчиненню кримінального правопорушення, та експерт виносить профілактичні пропозиції, які не були реалізовані під час розслідування провадження.

На нашу точку зору, недоцільний виклик експерта в судове засідання у наступних випадках:
- якщо його висновок обгрунтовано та останній узгоджується з іншими матеріалами справи (провадження);

- підозрюваний (обвинувачений) та інші зацікавлені учасники процесу не заперечують висновку експерта та не піднімають питання про необхідність виклику експерта у судове засідання;

- експерт встановлює такі несуттєві факти, які доведені іншими матеріалами провадження;

- у висновку експерта досліджені та вирішені питання, які виходять за межі його спеціальних знань;

- експерт відмовився від вирішення питання через непридатність об'єктів дослідження або наукової неопрацьованості методики їх дослідження.

Якщо суддя або суд у підготовчому судовому засіданні визнає недоцільним виклик експерта у судове засідання або якщо суд визнає можливим розглядати справу (провадження) за відсутності експерта, оскільки останній надав висновок на стадії досудового розслідування, цей висновок повинен бути оголошений та досліджений у судовому засіданні.

Ситуація друга.

Так, можлива ситуація, яка характеризується тим, що під час провадження дізнання чи досудового слідства не проводилася експертиза за обставинами, для встановлення яких потрібні спеціальні знання. Якщо ця обставина з'ясовується на стадії «віддання підозрюваного до суду» (передачі обвинувального акту до суду), то, як надав роз'яснення Пленум Верховного Суду України в постанові від 30 травня 1997 р.№ 8 у пункті 8 суддя або суд повинні з'ясувати можливість проведення відповідної експертизи під час судового розгляду справи. При вирішенні цього питання суд повинен взяти до уваги характер обставин, які підлягають дослідженню, їх значення для висновку про достатність підстав для подальшого обвинувачення підозрюваного, а також наявність можливості надання у розпорядження експерта в судовому засіданні матеріалів, що підлягають дослідженню. 


\section{Кримінальне право, кримінальний процес та криміналістика}

Іноді замість вирішення питання про можливість проведення експертизи у судовому засіданні суддя або суд призначає iii при вирішенні питання та з'ясуванні думки в учасників судового провадження щодо можливості призначення судового розгляду, тобто під час вивчення та підготовки справи до слухання - на етапі підготовчого провадження. На нашу думку, 3 такою практикою погодитися не можна. Оскільки призначення експертизи на стадії підготовчого провадження чинить «утиск» на законні інтереси обвинуваченого, тому що останній при цьому не наділений можливістю скористатися правами, наданими йому у статті 42 КПК України, та, таким чином, створюе штучні процесуальні перешкоди у реалізації вимог статті 345 КПК України. Пленум Верховного Суду України у постанові від 30 травня 1997 року № 8 надав роз'яснення, що проведення експертизи на стадії «віддання підозрюваного до суду» (підготовчого провадження) $\varepsilon$ неприпустимим. Призначення та проведення експертизи може мати місце тільки при судовому розгляді справи у порядку, встановленому кримінальним процесуальним законодавством України. Разом з тим для забезпечення проведення експертизи під час судового розгляду суддя або суд у підготовчому судовому засіданні наділені правом вирішити питання про виклик у судове засідання особи, яка має спеціальними знаннями, у тому числі, яка не проводила експертизу на стадії досудового розслідування.

Про виклик у судове засідання особи, яка володіє спеціальними знаннями, для проведення експертизи при судовому розгляді справи, на нашу думку, повинно бути вказано в ухвалі про призначення судового розгляду, яка виносяться у відповідності до статей 315-316 КПК України. Далі суд повинен вчинити процесуальні дії у відповідності до вимог статей 242 та 332 КПК України та з урахуванням вказівок, які містяться у постанові Пленуму Верховного Суду України від 30 травня 1997 року № 8 про те, що особа, яка володіє спеціальними знаннями та викликана до суду, може брати участь у дослідженні обставин справи, які стосуються предмета експертизи, лише після винесення ухвали про іiі призначення.

Проте, якщо при провадженні у кримінальних справах, розпочатих суддею не інакше як за скаргою потерпілого, для вирішення виниклих питань потрібні спеціальні знання, рішення про призначення експертизи може бути прийнято суддею i при відкритті провадження. Про це виноситься відповідна ухвала. При цьому повинні бути дотримані права підозрюваного при призначенні та проведенні експертизи, встановлені у статті 42 КПК України.

Третя ситуація.

у відповідності до статті 69 КПК України особа, яка викликана у судове засідання в якості експерта, бере участь у дослідженні доказів та може 3 дозволу суду ставити питання підсудному, потерпілому та свідкам за обставинами, які мають значення для висновку експерта. Цими правами користуються як експерти, які брали участь у проведенні експертизи на стадії досудового розслідування, так і експерти, призначені у суді.

Голова судового засідання зобов' язаний вжити всіх передбачених законом заходів для дослідження під час судового розгляду справи обставин, необхідних для дачі експертом висновку. Після з'ясування цих обставин голова пропонує прокуророві, підсудному, його захиснику та іншим учасникам судового засідання подати у письмовому вигляді питання, які вони бажають поставити перед експертизою. Якщо підсудний, потерпілий, цивільний позивач або цивільний відповідач або інші учасники судового розгляду не можуть через поважні причини у письмовому вигляді подати питання експерту, суд може дозволити їм викласти їх усно. Ці питання заносяться до протоколу судового засідання.

Суд повинен оголосити всі питання, які поставлені на вирішення експертного дослідження, та заслухати по них думку учасників судового розгляду, відхилити ті 3 них, які не стосуються справи або не належать до компетенції експерта, а також сформулювати ті питання, які він ставить перед експертом з власної ініціативи. Суд 
не пов’язаний формулюванням або переліком питань, запропонованих учасниками судового розгляду, а також поставлених перед експертом у процесі досудового розслідування.

Після визначення предмета експертного дослідження суд виносить ухвалу про призначення експертизи. У відповідності до статей 244 та 371 КПК України та пункту 9 постанови Пленуму Верховного Суду України від 30 травня 1997 року № 8 вона постановляється у нарадчій кімнаті та викладається у вигляді окремого документа, який підписується всім складом суду і підлягає оприлюдненню у судовому засіданні.

Зміст судової ухвали про призначення експертизи в основному аналогічний до змісту постанови про призначення експертизи, що складається при провадженні досудового слідства. У цьому визначенні, окрім питань, що виносяться судом на вирішення експерта, має бути зазначено, які питання учасників судового розгляду відхилені судом та мотиви їх відхилення. Пленум Верховного Суду України в постанові від 30 травня 1997 р. № 8 у пунктах 4 та 9 надав роз'яснення, що суд не має права замінити ухвалу про призначення експертизи іншими документами, не передбаченими законом (наприклад, супровідним листом, довідкою, списком питань експерту та інш.).

Інколи при розгляді справ, у яких експертиза проводилася на стадії досудового розслідування, у суду та учасників судового розгляду не виникає нових питань. Проте і в цьому випадку суди все ж таки призначають експертизи, ставлячи перед експертами питання про те, чи підтверджують вони висновки, які складені ними на стадії досудового розслідування. На нашу думку, у таких випадках не слід призначати експертизи, оскільки питання, які цікавлять суд, можна з'ясувати шляхом допиту експертів.

Четверта ситуація.

Якщо питання про необхідність проведення експертизи не обговорювалося на стадії підготовчого провадження, а виникає під час судового розгляду справи, суд зобов'язаний обговорити всі питання, пов'язані з призначенням і проведенням експертизи, та у разі наявності можливостей для її проведення у судовому засіданні викликати в суд особу, що володіє необхідними спеціальними знаннями. Далі суд діє відповідно до вимог статей 242 та 332 КПК України та постанови Пленуму Верховного Суду України від 30 травня 1997 p. № 8 .

У цьому випадку, якщо провести експертизу у судовому засіданні неможливо, суд, керуючись статтями 244 та 332 КПК України, виносить ухвалу про призначення експертизи, яку разом з усіма необхідними матеріалами направляє до судово-експертної установи, яка, у відповідності до вимог статей 69-70, 101-102 КПК України, повинна провести експертизу та скласти висновок.

Призначивши експертизу та вручивши ухвалу експерту або надіславши їі на виконання до судово-експертної установи, суд в залежності від тривалості майбутнього експертного дослідження та інших особливостей, пов'язаних з розглядом конкретної справи, повинен:

- оголосити на час до отримання висновку перерву або відкласти слухання справи;

- продовжити судове слідство, займаючись дослідженням інших доказів.

Експертне дослідження, виконання якого доручено експерту, який присутній у судовому засіданні, може проводитися як у приміщенні суду, так і за місцем знаходження необхідних для його здійснення приладів та обладнання.

Суд за клопотанням експерта може обмежити присутність останнього у судовому засіданні часом, необхідним для дослідження доказів, що мають відношення до предмету експертизи. Після складення висновку експертом та його допиту, після заслуховування думок прокурора, підсудного, захисника, потерпілого, цивільного позивача, цивільного відповідача та їх представників суд може звільнити експерта від подальшої присутності в суді. Про це зазначається у протоколі судового засідання.

При розгляді кримінальної справи у касаційному порядку суд не вправі при- 


\section{Кримінальне право, кримінальний процес та криміналістика}

значати експертизу, у тому числі додаткову або повторну.

При розгляді справ, у яких проводиться розслідування за нововиявленими обставинами, суддя, яка провадить розслідування, може в порядку статей 459 - 467 КПК України 3 дотриманням вимог статей 242 та 332 КПК України призначити експертизу.

Окрім того, необхідно зазначити, що законодавець в окремі «ситуаційні позиції〉 виніс можливість призначення комплексної психолого-психіатричної і психологічної експертизи неповнолітнього підозрюваного чи обвинуваченого у кримінальних провадженнях щодо неповнолітніх - стаття 486 КПК України; призначення та проведення психіатричної експертизи у кримінальних провадженнях щодо застосування примусових заходів медичного характеру - стаття 509 КПК України та розглянув Особливості проведення експертизи у кримінальному провадженні, яке містить державну таємницю - стаття 518 КПК України.

Як висновок до статті зазначимо, що наявність процесуальних ситуацій, які виникають у кримінальних провадженнях при призначенні експертизи в суді, різноманіття їх процесуальних варіації, а отже, як наслідок, неоднозначне науково-теоретичне трактування та застосування на практиці при здійсненні судового провадження вимагають від судових та експертних органів вдосконалення сучасних та розроблення нових методів призначення та проведення експертних досліджень у суді з метою якісного та ефективного виконання завдань та дотримання загальних засад кримінального провадження.

Зважаючи на наявність недоліків у цій сфері процесуально-правової, судової та експертної діяльності, вважаємо за актуальні подальші дослідження відповідної спрямованості, адже останні створюватимуть перспективи теоретичних та практичних напрацювань та сприятимуть розв'язанню проблемних питань на цьому напрямку.

\section{Мiтература}

1. Конституція України. Відомості Верховної Ради України (ВВР), 1996, № 30, ст.141) (редакція станом на 02.12.2019) [Електронний ресурс] : http://zakon.rada.gov. uа (дата звернення: 07.09.2021).

2. Кримінальний процесуальний кодекс України. Відомості Верховної Ради України (ВВР), 2013, № 9-10, № 11-12, № 13 ст.88. (редакція станом на 15.07.2021) [Електронний ресурс] : http://zakon.rada.gov.ua (дата звернення: 07.09.2021).

3. Закон України «Про судову експертизу» від 25.02.94 №4038-XII. Відомості Верховної Ради України (ВВР), 1994, № 28, ст.232) (редакція станом на 15.12.2020) [Електронний ресурс] : http://zakon.rada.gov. uа (дата звернення: 07.09.2021).

4. Закон України «Про психіатричну допомогу» від 22.02.2000 №1489-III. Відомості Верховної Ради України (ВВР), 2000,№ 19, ст.143) (редакція станом на 20.12.2018) [Електронний ресурс] : http://zakon.rada.gov. uа (дата звернення: 07.09.2021).

5. Кримінальний кодекс України. Відомості Верховної Ради України (ВВР), 2001, № 25-26, ст.131. (редакція станом на 15.07.2021) [Електронний ресурс] : http://zakon.rada.gov.ua (дата звернення: 07.09.2021).

6. Експерт // Юридична енциклопедія : [у 6 т.] / ред. кол. Ю. С. Шемшученко (відп. ред.) [та ін.]. - К. : Українська енциклопедія ім. М. П. Бажана, 1998. - Т. 2 : Д.-Й. -744 c.

7. Експерт // Термінологічний словник 3 питань запобігання та протидії легалізації (відмиванню) доходів, одержаних злочинним шляхом, фінансуванню тероризму, фінансуванню розповсюдження зброї масового знищення та корупції / А. Г. Чубенко, М. В. Лошицький, Д. М. Павлов, С. С. Бичкова, О. С. Юнін. - Київ : Ваіте, 2018. - C. $246-247$.

8. Постанова Пленуму Верховного Суду України «Про судову експертизу в кримінальних і цивільних справах» від 30 травня 1997 року № 8 (редакція станом на 25.05.1998) [Електронний ресурс] : http://search.ligazakon.ua (дата звернення: 07.09.2021). 
Осмолян В.А. - Розгляд та вирішення процесуальних ситуацій, які виникають...

\section{АНОТАЦІЯ}

У статті автор викладає правові основи та перспективи розвитку судової експертизи та кримінального прочесуального права у світлі правової реборми в Украӥни. Розглядаються прочесуальні ситуаиій, які виникають в суді при судовому розгляді кримінальних справ, досліджуються та аналізуються питання щодо можливості призначення та проведення експертизи у кримінальному провадженні в суді, а також обгрунтовується необхідність ефективної співпраці працівників суду та експертів (спеціалістів) для якісного та об'єктивного виконання завдань кримінального провадження, дотримання загальних засад кримінального провадження та покращення інновачійної політики України загалом. Сфбормовані та наведені пропозицй шьодо покращення методики призначення експертизи під час розгляду кримінальних справ судом. Автором надані власні (авторсъкі) пропозищй щодо вирішення можливих процесуальних труднощів при призначенні експертизи в суді. Розкривається значення та місце изх новел у системі права, судової експертизи та кримінального процесу в иілому. Зроблені висновки та надані рекомендації щодо узгодженого застосування норм иинного законодавства у практичній діяльності експерта та судді. Привернуто увагу на необхідність подальшої наукової співпраці вчених, спеціалістів у галузі матеріального та процесуального права.

Ключові слова: дослідження, експертиза, суд, суддя, сторони, спещіаліст, кримінальний прочес, кримінальне провадження.

\section{Osmolian V.A. CONSIDERATION AND RESOLUTION OF PROCEDURAL SITUATIONS THAT ARISE IN GRIMINAL PROGEEDINGS WHEN APPOINTING AN EXPERT IN COURT}

The author outlines the legal basis and prospects for the development of forensic science and criminal procedural law in the light of legal reform in Ukraine. Procedural situations that arise in court during the trial of criminal cases are considered. The author also examines and analyzes the possibility of appointing and conducting an examination in criminal proceedings in court. The article substantiates the need for effective cooperation between court staff and experts (specialists) for the quality and objective implementation of the tasks of criminal proceedings, compliance with the general principles of criminal proceedings and improving the innovation policy of Ukraine as a whole. The proposals on improvement of a technique of appointment of examination during consideration of criminal cases by court are formed and resulted. The author provides his own (author's) proposals for resolving possible procedural difficulties in appointing an expert in court. The significance and place of these short stories in the system of law, forensic science and criminal proceedings in general are revealed. Conclusions are made and recommendations are given regarding the coordinated application of the norms of the current legislation in the practical activity of the expert and the judge. Attention is drawn to the need for further scientific cooperation of scientists, specialists in the field of substantive and procedural law.

Keywords: research, examination, court, judge, parties, specialist, criminal proceedings, criminal case. 